\title{
DIET AND CAPTURE OF Hypostomus strigaticeps (SILURIFORMES, LORICARIIDAE) IN A SMALL BRAZILIAN STREAM: RELATIONSHIP WITH LIMNOLOGICAL ASPECTS
}

\author{
CARDONE, I. B. ${ }^{1}$, LIMA-JUNIOR, S. E. ${ }^{2}$ and GOITEIN, R. ${ }^{1}$ \\ ${ }^{1}$ Departamento de Zoologia, Universidade Estadual Paulista, Av. 24-A, 1515, C. P. 199, CEP 13506-900, Rio Claro, SP, Brazil \\ ${ }^{2}$ Laboratório de Análise e Monitoramento Ambiental do Gás Natural (GASLAB), \\ Universidade Estadual de Mato Grosso do Sul, Rodovia Dourados-Itahum, \\ Km 12, CEP 79804-970, Dourados, MS, Brazil \\ Correspondence to: Isabella Braz Cardone, Departamento de Zoologia, Universidade Estadual Paulista, Av. 24-A, 1515, \\ C. P. 199, CEP 13506-900, Rio Claro, SP, Brazil, e-mail: belcardone@ hotmail.com \\ Received August 9, 2004 - Accepted November 24, 2004 - Distributed February 28, 2006
}

(With 4 figures)

\begin{abstract}
The purpose of this study is to ascertain whether variations in the limnological parameters of the Corumbataí river resulting from the discharge of a variety of wastes into its waters may be responsible for spatial shifts in the diet and capture of the armored catfish Hypostomus strigaticeps (Regan, 1907). Individuals were collected over a period of two years from two sites with similar physical, albeit distinct limnological characteristics. As a whole, the environmental variables (temperature, $\mathrm{pH}$, dissolved oxygen, electrical conductivity, and total coliforms and fecal coliforms) of the two sites were found to vary significantly. The food items found in the guts of these armored catfish (sediments, diatoms, fungi hyphae, chlorophytes, cyanophytes and non-identified material) ranked differently in samples from the two sites. In the more polluted (site B), diatoms and chlorophytes ranked higher in the diet than in that of individuals caught in the more preserved location (site A). This fact may be related to the greater amount of organic material found at site $\mathrm{B}$, which provides favorable environmental conditions for such algae and, consequently, for algivorous fishes. Even so, fewer fish were captured at site B than at site A, suggesting that although food is more abundant in the more polluted site, its limnological conditions appear, on the whole, to be less beneficial than the conditions at site A.
\end{abstract}

Keywords: Hypostomus, Corumbataí river, environmental impact, fish, pollution.

\section{RESUMO}

\section{Dieta e captura de Hypostomus strigaticeps (Siluriformes, Loricariidae) em um pequeno riacho brasileiro: relação com aspectos limnológicos}

O propósito deste estudo é investigar se as variações dos parâmetros limnológicos do rio Corumbataí - como uma consequiência do lançamento de dejetos em suas águas - é responsável por variações na dieta e na captura do cascudo Hypostomus strigaticeps (Regan, 1907). Os indivíduos foram coletados durante dois anos em dois pontos do rio, com características físicas semelhantes, mas sujeitos a diferentes condições limnológicas; as variáveis ambientais (temperatura, $\mathrm{pH}$, oxigênio dissolvido, condutividade elétrica, coliformes totais e coliformes fecais), quando consideradas conjuntamente, variaram significativamente entre os locais. As categorias alimentares encontradas nos tubos digestórios dos cascudos (sedimento, material não identificado, hifas de fungo, diatomáceas, clorófitas e cianófitas) apresentaram ordenamento hierárquico distinto nas amostras provenientes de diferentes pontos do rio. No local mais poluído (ponto B), diatomáceas e clorófitas ocuparam postos mais importantes em relação ao observado na dieta dos indivíduos coletados no ponto mais preservado (ponto A). Este resultado possivelmente esteja relacionado à maior concentração de matéria orgânica observada no ponto B, propiciando condições ambientais favoráveis 
à proliferação de algas e, conseqüentemente, para um peixe comedor de algas. Contudo, o número de indivíduos capturados no ponto B foi menor, sugerindo que, embora a oferta de alimento seja mais abundante no local mais alterado, as condições limnológicas neste ponto, quando consideradas em seu conjunto, são possivelmente menos benéficas para a sobrevivência da espécie que as condições observadas no ponto A.

Palavras-chave: Hypostomus, rio Corumbataí, impacto ambiental, peixe, poluição.

\section{INTRODUCTION}

Mankind's influence on ecosystems is almost always negative (Odum, 1986). In water systems, for example, anthropic interference seriously impacts aquatic organisms, possibly leading to the disappearance of many fish species and affecting their diversity (Malins \& Ostrander, 1994; Magurran \& Phillip, 2001). In this context, studies of the possible effects of environmental alterations on fish biology serve to evaluate the extent of damage caused by humans to aquatic systems.

The investigation of the diet of a particular fish species is a valuable tool, aiding in the interpretation of the trophic relationships established in water ecosystems (Hahn et al., 1997) by providing information about the life of the fish, such as its position in the food web, the food resources it uses and its possible competitors (Schoener, 1974).

The system selected for this study was the Corumbataí river, a small Brazilian river that supplies potable water to approximately 600.000 inhabitants, including those of larger cities such as Rio Claro and Piracicaba, in the state of São Paulo. However, its use has not been carefully planned, for the river is also the recipient of domestic, industrial and agricultural wastes and its water quality varies considerably from one section to another.

Hypostomus strigaticeps (Regan, 1907) is one of the most abundant and widely distributed species in the Corumbataí river. Like other loricariids (Siluriformes, Loricariidae), it exhibits important functional adaptations - ventral mouth, modified lips forming an adherent sucker and teeth resembling spatulae - to scrape its food from a variety of substrates (Shaefer \& Lauder, 1986; Delariva \& Agostinho, 2001), for it feeds mainly off diatoms and periphyton (Power, 1984; 1990). Another feature of the genus Hypostomus that differentiates it from other loricariids is its greater ability to breathe atmospheric air. The stomach walls of this armored catfish are abundantly embedded with veins that allow gaseous exchanges between the swallowed air and the blood (Armbruster, 1998). According to Val \& Almeida-Val (1995), it may be classified in a group of fishes that display accessory breathing, using this strategy when the water conditions are severely hypoxic.

Considering that armored catfish are fairly resistant to altered environments, since they have accessory breathing, and eat algae, whose growth is maximized in waters with a high level of organic material (Harper, 1992; Wetzel, 1993), the purpose of this study is to investigate whether variations in the limnological parameters of the Corumbataí river - as a result of the different wastes it receives - may be responsible for spatial shifts in the diet and abundance of $H$. strigaticeps.

\section{MATERIAL AND METHODS}

Two sites in the Corumbataí river were sampled bimonthly between June 2000 and April 2002, totaling 12 paired samples. These sites have similar physical characteristics - border vegetation, channel sinuosity, rock basement, substratum type, declivity, horizontal and vertical dissection and relief energy, but their limnological conditions are distinct. Site A $\left(22^{\circ} 12^{\prime} 47^{\prime \prime} \mathrm{S}\right.$ and $47^{\circ} 37^{\prime} 40^{\prime \prime} \mathrm{W}$ ) is located upstream from the river's main sources of pollution (Fig. 1). Site B (22 ${ }^{\circ} 32^{\prime}$ $31^{\prime \prime} \mathrm{S}$ and $47^{\circ} 40^{\prime} 09^{\prime \prime} \mathrm{W}$ ), on the other hand, is located downstream from the sites where domestic and industrial wastes from several cities flow into the river (Fig. 1).

Four water parameters were measured at the fish collection sites: temperature $\left({ }^{\circ} \mathrm{C}\right), \mathrm{pH}$ ( $\mathrm{pH}$ units), dissolved oxygen (mg. $\mathrm{L}^{-1}$ ) and electrical conductivity $\left(\mu \mathrm{S} . \mathrm{cm}^{-1}\right)$. In addition, the relative 

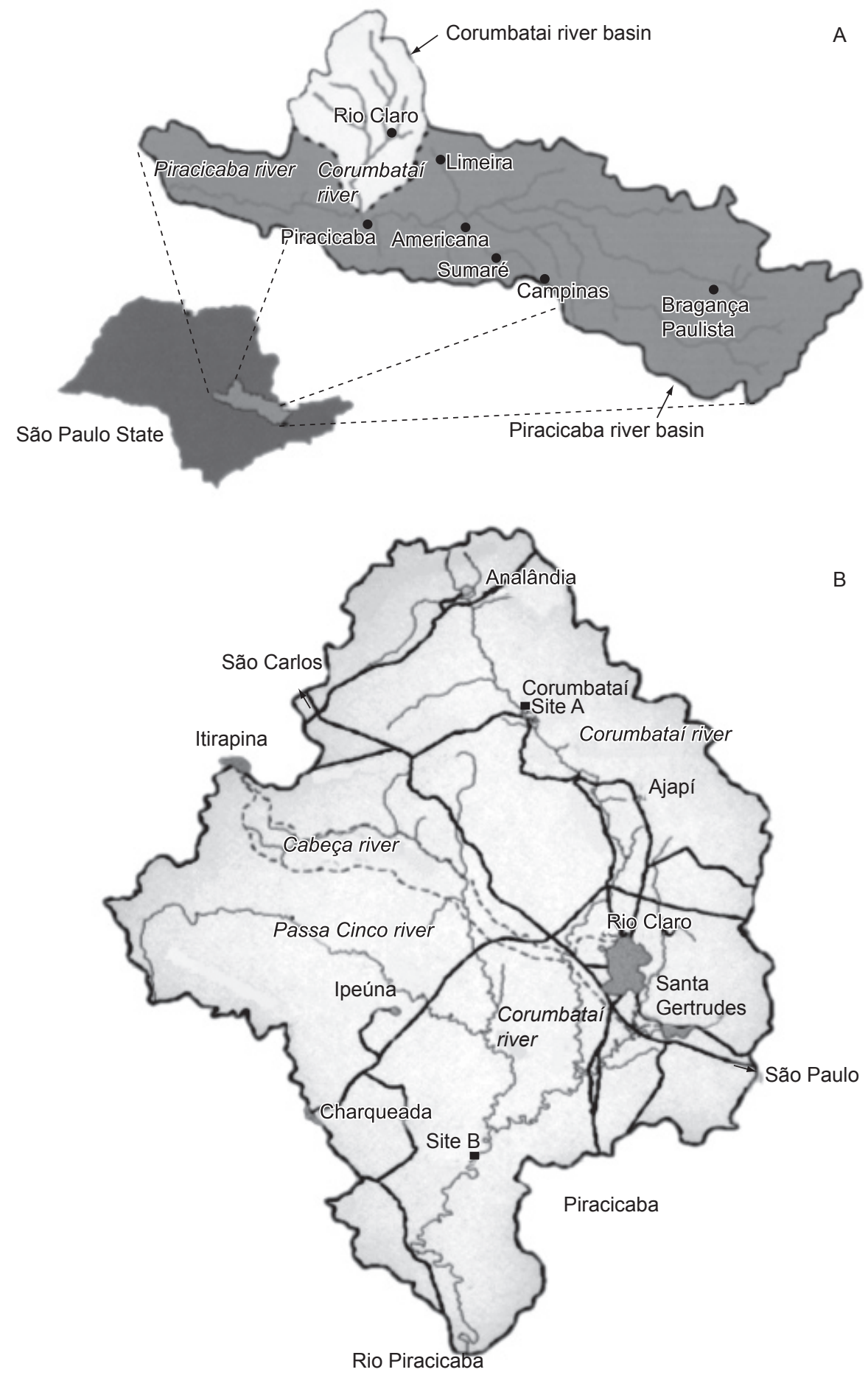

Fig. 1 - Corumbataí Basin in the state of São Paulo (A) and Corumbataí Basin in detail (B), indicating the fish collection sites (adapted from the original: Atlas, 2001). 
amount of total and fecal coliforms present in water samples was measured in the laboratory after incubation at $35^{\circ} \mathrm{C}$ for $24 \mathrm{~h}$. The results of these variables were obtained in triplicate samplings and transformed into means for each of the 12 samples collected at each site. The means of each site were then compared for each sample, using the $t$-test ( $\alpha=0.05$ ) as described by Zar (1996).

Fish were caught using gill nets (mesh size $1.5,2.0,4.0$ and $6.0 \mathrm{~cm}$ between knots) and cast nets (mesh size 1.2, 2.0 and $3.5 \mathrm{~cm}$ between opposite knots), applying the same fishing effort for all the samples. To test the null hypothesis that the number of fish captured would not differ between sites, the data obtained for the 12 samples were compared using the Mann-Whitney test (Zar, 1996), assuming the alternative hypothesis at $\mathrm{p}<0.05$.

In the laboratory, the gut of each individual was weighed (in g, to the nearest $0.01 \mathrm{~g}$ ) and preserved in a $70 \%$ ethanol solution until the analysis. Because the stomach contents are difficult to recognize, these analyses were done using the material collected from the anterior third section of the digestive tract containing the more recently ingested food, which is in a better state for identification.

The gut contents were diluted in water and shaken toobtain ahomogeneous extract. Subsamples from these extracts were inspected microscopically and each recognized food item was assigned a value proportional to its abundance. The reference used for these values was the standard weight (SW), which is the approximate arithmetic mean of the weight of the sample's gut content, as proposed by Lima-Junior \& Goitein (2001). Assuming that the $\mathrm{SW}$ ( $4.0 \mathrm{~g}$ in this study) is equivalent to 4 points, the gut contents were initially assigned a total value, according to the proportion of their mass in relation to the SW. Based on a simple visual inspection, this total value was then divided among the food items, according to their relative volume.

To analyze the data in terms of the species' diet, the individuals caught at different sites were considered separate samples. The Importance Index of the food items was then calculated according to the method described by Lima-Junior \& Goitein (2001) and used by Lima-Junior \& Goitein (2003), whereby the sum of points attributed to each food item, divided by the total number of guts in the sample, resulted in the mean of the ascribed values of each food item. This mean was multiplied by 25 to transform it into a percent value, the so-called Volumetric analysis index $\left(\mathrm{V}_{\mathrm{i}}\right)$. The result obtained by the multiplication of $\mathrm{V}_{\mathrm{i}}$ by the frequency of occurrence (Hyslop, 1980) of each item corresponds to the Importance Index of the food item in the sample.

These results were statistically analyzed applying the method described by Fritz (1974), in which the food items are ranked in each sample and compared using the Spearman rank correlation coefficients. The correlation was considered statistically significant at $\mathrm{p}<0.05$.

\section{RESULTS}

\section{Limnological parameters}

The temperature variations were considered normal within the region's climatic pattern. Thus, the maximum temperatures were recorded during the warmer months and the lowest ones during the colder months. Although some slightly higher temperatures were observed at site $\mathrm{B}$, the differences between sites were not statistically significant (Fig. 2a, Table 1).

The results of the $\mathrm{pH}$ analyses at the two sites revealed an irregular pattern, demonstrating that these places did not differ markedly in relation to this parameter (Fig. 2b, Table 1).

On the other hand, the results obtained for dissolved oxygen, electrical conductivity and number of coliforms (total and fecal) presented significant differences between the sites in almost all the samplings (Fig. 2c-f, Table 1), indicating that site $\mathrm{B}$ was more highly impacted and had worse water quality than site $\mathrm{A}$.

\section{Capture}

The total number of individuals caught at site $\mathrm{A}$ was more than twice the number caught at site $B\left(n_{A}=634\right.$ and $\left.n_{B}=304\right)$. The result of the Mann-Whitney test, obtained by comparing the series of data from the two sites throughout the whole period (Fig. 3), confirmed the significance of this difference in the capture of individuals $(\mathrm{p}=0.0242)$.

\section{Diet}

It was observed that $H$. strigaticeps at the two sites on the Corumbataí river consumed 

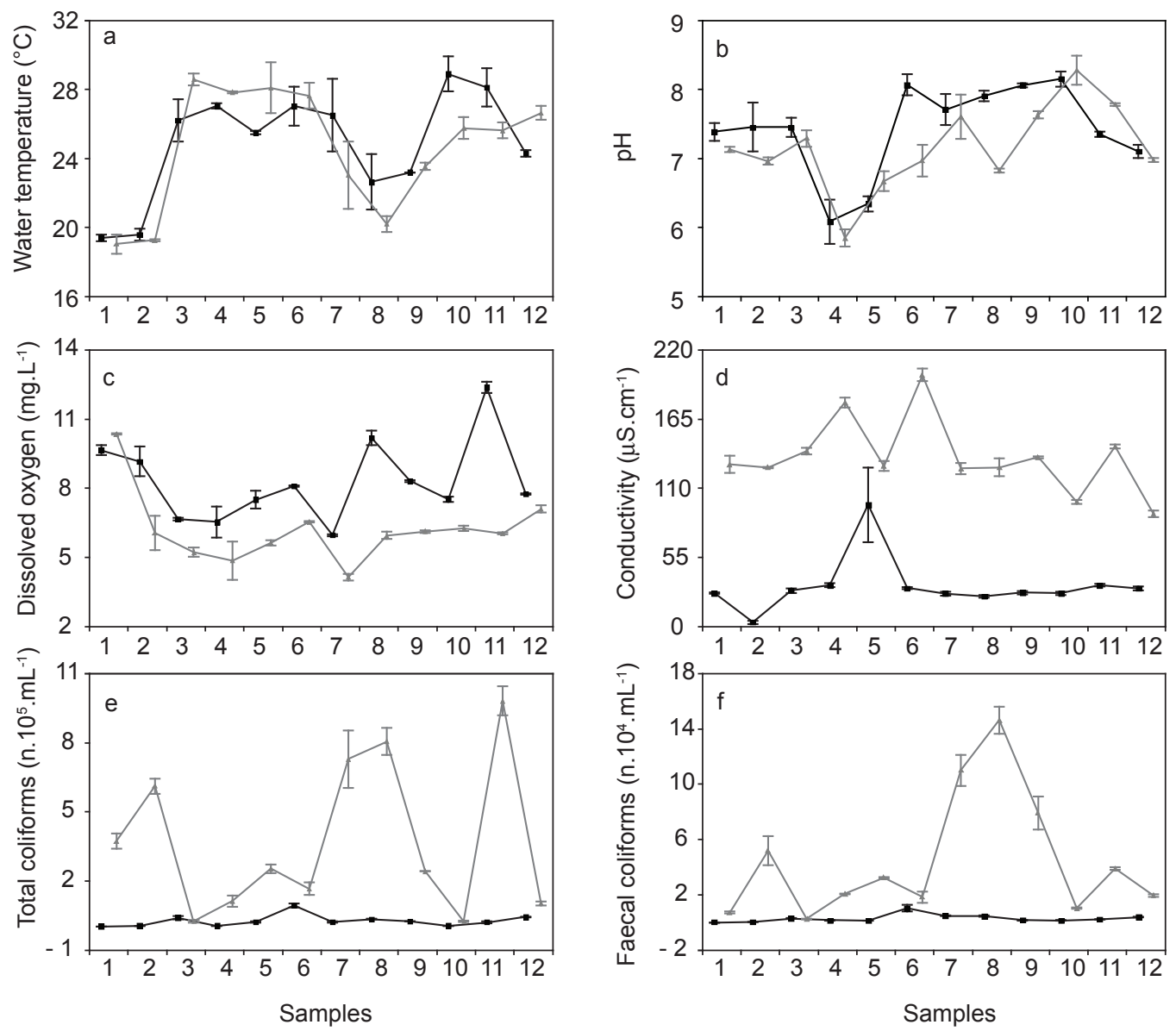

Fig. 2 - Mean values ( \pm standard deviation) of the limnological parameters in each sample. Black lines represent the data for site $\mathrm{A}$ and gray lines represent data for site $\mathrm{B}$.

TABLE 1

Statistical comparison ( $t$-test) of the sites according to the limnological parameters of each sample. The significant differences are highlighted in bold $(p<0.05)$.

\begin{tabular}{|c|c|c|c|c|c|c|}
\hline Sample & Water temperature & $\mathbf{p H}$ & Dissolved oxygen & Conductivity & Total coliforms & Fecal coliforms \\
\hline 1 & 0.3394 & $\mathbf{0 . 0 3 0 2}$ & $\mathbf{0 . 0 0 4 5}$ & $<\mathbf{0 . 0 0 0 1}$ & $<\mathbf{0 . 0 0 0 1}$ & $\mathbf{0 . 0 0 0 1}$ \\
\hline 2 & 0.1755 & 0.0759 & $\mathbf{0 . 0 0 5 4}$ & $<\mathbf{0 . 0 0 0 1}$ & $<\mathbf{0 . 0 0 0 1}$ & $\mathbf{0 . 0 0 1 1}$ \\
\hline 3 & $\mathbf{0 . 0 3 0 3}$ & 0.1962 & $\mathbf{0 . 0 0 0 3}$ & $<\mathbf{0 . 0 0 0 1}$ & $\mathbf{0 . 0 4 7 5}$ & 0.2379 \\
\hline 4 & $\mathbf{0 . 0 0 1 1}$ & 0.2934 & 0.0537 & $<\mathbf{0 . 0 0 0 1}$ & $\mathbf{0 . 0 0 2 0}$ & $<\mathbf{0 . 0 0 0 1}$ \\
\hline 5 & $\mathbf{0 . 0 3 8 5}$ & $\mathbf{0 . 0 3 4 0}$ & $\mathbf{0 . 0 0 1 3}$ & 0.1482 & $<\mathbf{0 . 0 0 0 1}$ & $<\mathbf{0 . 0 0 0 1}$ \\
\hline 6 & 0.4826 & $\mathbf{0 . 0 0 2 3}$ & $<\mathbf{0 . 0 0 0 1}$ & $<\mathbf{0 . 0 0 0 1}$ & $\mathbf{0 . 0 1 3 3}$ & $\mathbf{0 . 0 4 5 4}$ \\
\hline 7 & 0.1043 & 0.6701 & $<\mathbf{0 . 0 0 0 1}$ & $<\mathbf{0 . 0 0 0 1}$ & $\mathbf{0 . 0 0 0 6}$ & $\mathbf{0 . 0 0 0 1}$ \\
\hline 8 & 0.0652 & $<\mathbf{0 . 0 0 0 1}$ & $<\mathbf{0 . 0 0 0 1}$ & $<\mathbf{0 . 0 0 0 1}$ & $<\mathbf{0 . 0 0 0 1}$ & $<\mathbf{0 . 0 0 0 1}$ \\
\hline 9 & 0.0502 & $\mathbf{0 . 0 0 0 3}$ & $<\mathbf{0 . 0 0 0 1}$ & $<\mathbf{0 . 0 0 0 1}$ & $<\mathbf{0 . 0 0 0 1}$ & $\mathbf{0 . 0 0 0 3}$ \\
\hline 10 & $\mathbf{0 . 0 1 0 7}$ & 0.4225 & $\mathbf{0 . 0 0 0 2}$ & $<\mathbf{0 . 0 0 0 1}$ & $\mathbf{0 . 0 0 0 5}$ & $<\mathbf{0 . 0 0 0 1}$ \\
\hline 11 & $\mathbf{0 . 0 2 2 5}$ & $\mathbf{0 . 0 0 0 1}$ & $<\mathbf{0 . 0 0 0 1}$ & $<\mathbf{0 . 0 0 0 1}$ & $<\mathbf{0 . 0 0 0 1}$ & $<\mathbf{0 . 0 0 0 1}$ \\
\hline 12 & $\mathbf{0 . 0 0 0 9}$ & 0.1037 & $\mathbf{0 . 0 0 2 1}$ & $<\mathbf{0 . 0 0 0 1}$ & $\mathbf{0 . 0 0 0 3}$ & $<\mathbf{0 . 0 0 0 1}$ \\
\hline
\end{tabular}




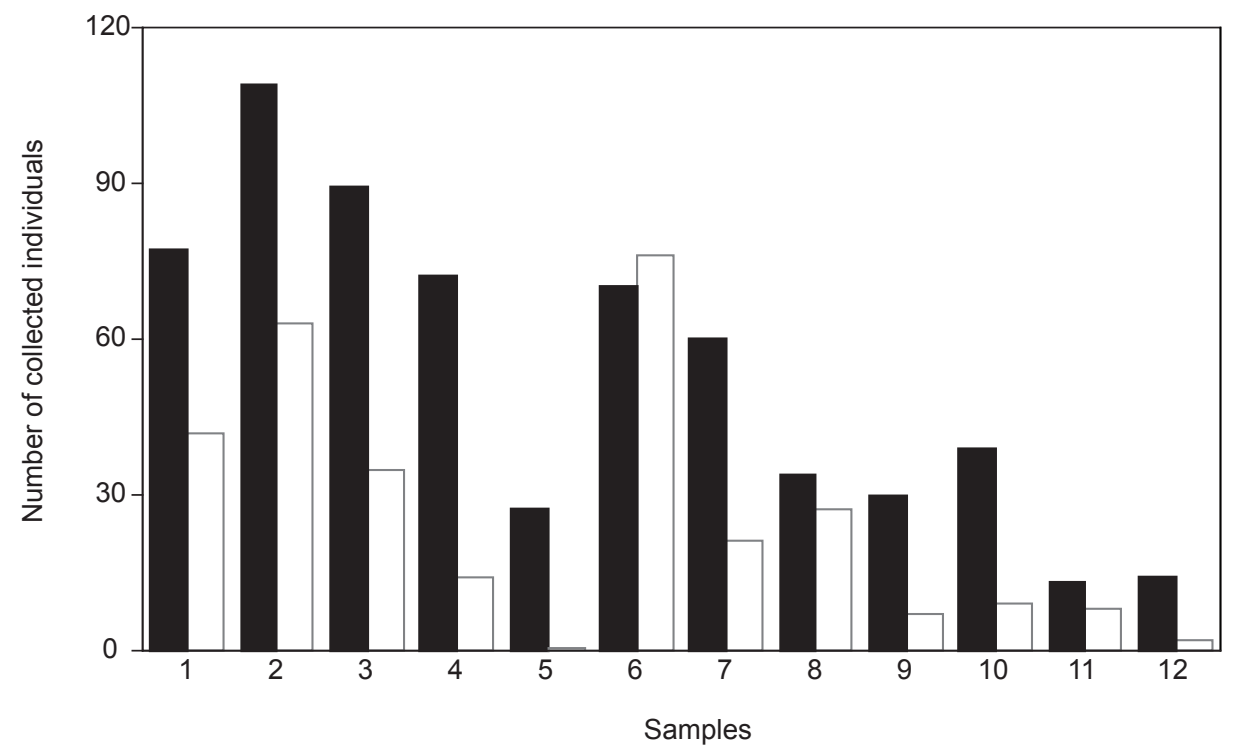

Fig. 3 - Number of individuals collected in each sample. Black bars represent the data for site A and gray bars represent data for site B.

diatoms (Navicula, Nitzschia and Melosira), fungi hyphae (Trichoderma), chlorophytes (Closterium and Oedogonium) and cyanophytes (Lyngbya and Oscilatoria), as well as a considerable amount of sediment (sand and mud) and undentified material (detritus of uncertain composition - organic or inorganic). Despite the similarity of the diet at the two sites, the statistical comparison of the Importance Index (Spearman rank correlation coefficient) did not indicate a significant correlation between the sites for most of the samples. Thus, it can be stated that there were differences in the importance hierarchy of the food items ingested by the individuals collected at each location (Fig. 4, Table 2). In fact, an analysis of the diet of individuals collected at sites A and B indicated that diatoms and chlorophytes ranked higher in the diet at site B.

\section{DISCUSSION}

The analysis of the diet of $H$. strigaticeps clearly showed, in almost all the samples, that the individuals captured at site B consumed diatoms and chlorophytes (green algae) more often and more intensely that those captured at site $\mathrm{A}$ in the Corumbataí river. These findings suggest that armored catfish, which are grazing animals that feed mainly on algae (Shaefer \& Lauder, 1986; Power, 1990), encounter greater food availability at site B. This may be explained by the higher levels of pollution, as indicated by the concentration of dissolved oxygen, electrical conductivity, and quantity of total and fecal coliforms found at this site. The direct consequence of this process is an increase in the concentration of nutrients (artificial eutrophication), which in turn leads to a proliferation of the algae population (Harper, 1992; Wetzel, 1993).

Since sediment ingestion depends on how these fish graze their food from the substrate, swallowing it in large amounts simultaneously with organic components, the higher importance indices observed in site A samples provide reinforcing evidence that food availability is lower in this location, since armored catfish would ingest higher volumes of sand and mud to obtain sufficient food usually mixed with the sediment. The microscopic analysis of the gut contents confirmed that the most important food items - diatoms, fungi hyphae and unidentified material - were, in fact, associated with the sediment.

Matthews \& Berg (1997) stated that low oxygen rates would be expected to have a negative effect on fish, inducing them to migrate in search of other places with better oxygen concentration. Although 

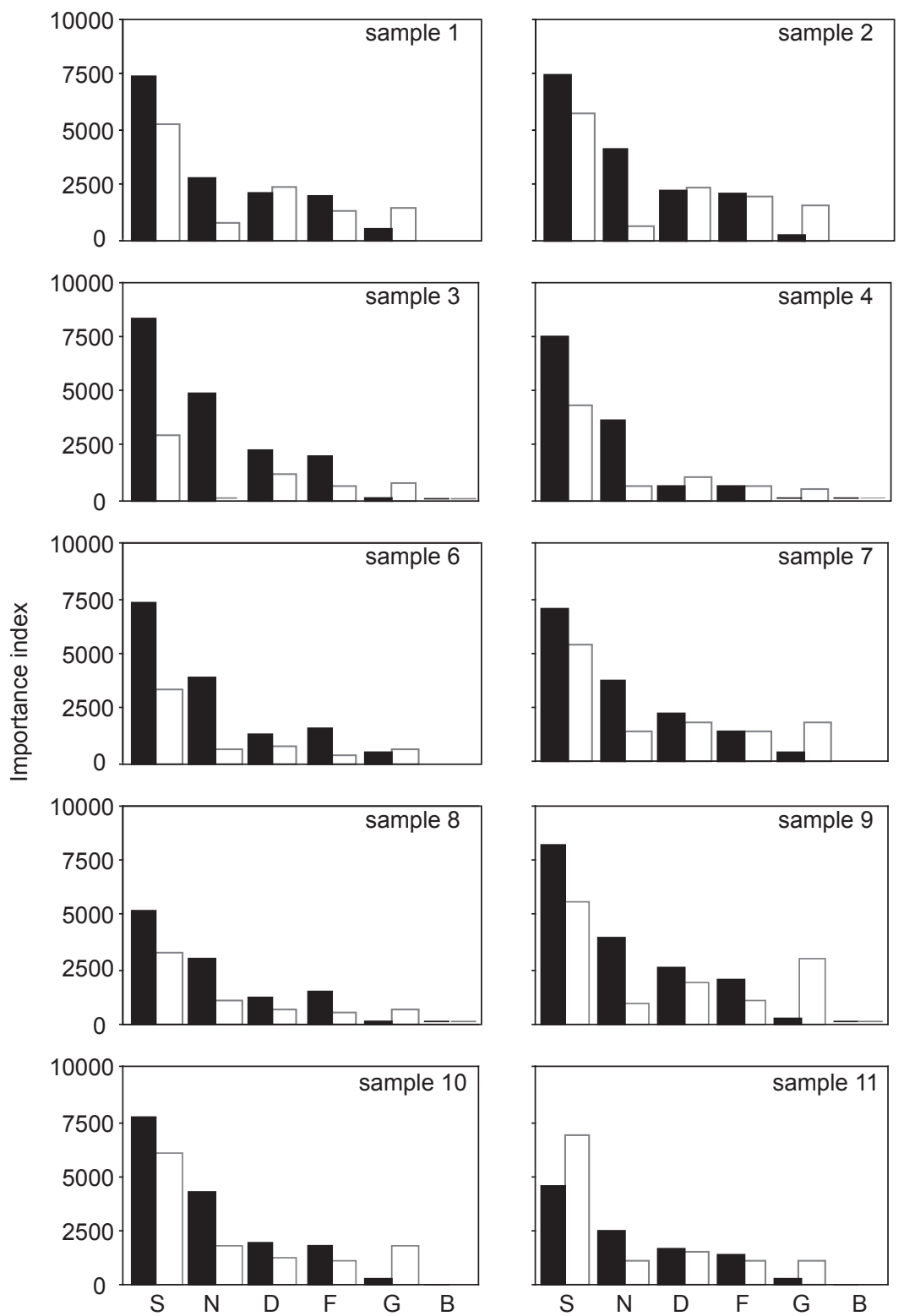

Food items

Fig. 4 - Importance index of the food items consumed by H. strigaticeps in each sample. Black bars represent the data for site $\mathrm{A}$ and gray bars represent the data for site $\mathrm{B} . \mathrm{S}=$ sediment; $\mathrm{N}=$ non-identified material; $\mathrm{D}=$ diatoms; $\mathrm{F}=$ fungi hyphae; $\mathrm{G}=$ chlorophytes (green algae); and $\mathrm{B}=$ cyanophytes (blue algae).

this may be discussed in the case of $H$. strigaticeps, which is an alternative breathing species that uses its stomach to carry out gaseous exchanges (Val \& Almeida-Val, 1995; Armbruster, 1998), a fewer individuals were caught at site $\mathrm{B}$. This fact indicates that site A probably offered better conditions for the species' survival, considering that the same fishing effort was applied in both locations.

High concentrations of metal ions are known to affect the respiratory and osmoregulatory functions of fish, increasing the mortality rate of individuals (Poléo et al., 1997; Playle, 1998; Gensemer \& Playle, 1999). Thus, the hypothesis 
TABLE 2

Statistical comparison (Spearman rank correlation) of the sites according to the food items ranking in each sample. The significant correlation coefficients are highlighted in bold $(p<0.05)$.

\begin{tabular}{|c|c|}
\hline Sample & $\mathbf{r}$ \\
\hline 1 & 0.6000 \\
\hline 2 & 0.6571 \\
\hline 3 & 0.6000 \\
\hline 4 & $\mathbf{0 . 8 2 8 6}$ \\
\hline 6 & 0.5429 \\
\hline 7 & 0.6000 \\
\hline 8 & $\mathbf{0 . 8 2 8 6}$ \\
\hline 9 & 0.4857 \\
\hline 10 & 0.7537 \\
\hline 11 & $\mathbf{0 . 8 1 9 7}$ \\
\hline
\end{tabular}

can be put forward that $H$. strigaticeps is sensitive to inorganic pollution, since the moderate process of eutrophication to which it is subjected at site B on the Corumbataí river may not, per se, impose restrictions on the survival of the species, but instead, contribute to an increase in the supply of its main food source. However, the higher concentration of metal ions in the water may be a decisive factor contributing to the lower number of individuals captured at this location. This possibility, however, would require a separate study since it lay outside the scope of this one. This hypothesis may be corroborated by other researchers who, upon examining the effects of water quality on another armored catfish, discovered a direct relationship between the level of water pollution and the occurrence of wounds and histopathological alterations affecting fish health (Flores-Lopes et al., 2001). In addition, fish affected by dysplasia showed lower survival chances, and were more easily eliminated from the population (Bergman, 1985).

As a final consideration, one may conclude that there is a strong relationship between the limnological conditions of the Corumbataí river and the diet of $H$. strigaticeps and, although the food supply may be greater at the most highly impacted site, the limnological conditions may, on the whole, be more adverse for the survival of the species than the conditions at the more preserved site.
Acknowledgments - We thank the Brazilian agencies FAPESP (Process 99/11459-5) and CAPES for their financial assistance and Centro de Estudos Ambientais (CEA-Unesp) for the limnological analyses.

\section{REFERENCES}

ARMBRUSTER, J. W., 1998, Modifications of the digestive tract for holding air in loricariid and scoloplacid catfishes. Copeia, 1988: 663-675.

ATLAS, Ambiental da Bacia do rio Corumbataí: banco de dados preparado pelo Centro de Análise e Planejamento Ambiental, IGCE, Unesp, Rio Claro, 2001, Available from URL: http://www.rc.unesp.br/igce/ceapla/atlas/atlas.swf Access in: Jan. 20, 2003.

BERGMAN, H., 1985, Assessment protocols for the identification and quantification of injury to fishery resources. Progress Report, Washington, 98p.

DELARIVA, R. L. \& AGOSTINHO, A. A., 2001, Relationship between morphology and diets of six Neotropical loricariids. J. Fish Biol., 58: 832-847.

FLORES-LOPES, F., MALABARBA, L. R., PEREIRA, E. H. L. \& SILVA, J. F. P., 2001, Alterações histológicas em placas ósseas do peixe cascudo Rineloricaria strigilata (Hensel) (Teleostei, Loricariidae) e sua freqüência no lago Guaíba, rio Grande do Sul, Brasil. Rev. Brasil. Zool., 18: 699-709.

FRITZ, E. S., 1974, Total diet comparison in fishes by Spearman rank correlation coefficients. Copeia, 1974: 210-214.

GENSEMER, R. W. \& PLAYLE, R. C., 1999, The bioavailability and toxicity of aluminum in aquatic environments. Critical Reviews in Environmental Science Technology, 29: 315-450.

HAHN, N. S., AGOSTINHO, A. A. \& GOITEIN, R., 1997, Feeding ecology of curvina Plagioscion squamosissimus (Heckel, 1840) (Osteichthyes, Perciformes) in the Itaipu Reservoir and Porto Rico floodplain. Acta Limnol. Bras., 9: 11-22. 
HARPER, D., 1992, Eutrophication of freshwater. Chapman \& Hall, London, 327p.

HYSLOP, E. J., 1980, Stomach content analysis - a review of methods and their applications. J. Fish Biol., 17: 411-429.

LIMA-JUNIOR, S. E. \& GOITEIN, R., 2001, A new method for the analysis of fish stomach contents. Acta Scientiarum, 23: 421-424.

LIMA-JUNIOR, S. E \& GOITEIN, R., 2003, Ontogenetic diet shits of a Neotropical catfish, Pimelodus maculatus (Siluriformes, Pimelodidae): An ecomorphological approach. Environ. Biol. Fishes, 68: 73-79.

MAGURRAN, A. E. \& PHILLIP, D. A T., 2001, Implications of species loss in freshwater fish assemblages. Ecography, 24: 645-650.

MALINS, D. C. \& OSTRANDER, G. K., 1994, Aquatic toxicology: molecular, biochemical, and cellular perspectives. CRC Press, Florida, 539p.

MATTHEWS, K. R. \& BERG, N. H., 1997, Rainbow trout responses to water temperature and dissolved oxygen stress in two southern California stream pools. J. Fish Biol., 50: $50-67$.

ODUM, E. P., 1986, Ecologia. Guanabara Koogan, rio de Janeiro, 434p.

PLAYLE, R. C., 1998, Modeling metal interactions at fish gills. The Science of the Total Environment, 219: 147-163.
POLÉO, A. B. S., OSTBYE, K., OXNEVAD, S. A, ANDERSEN, R. A, HEIBO, E. \& VOLLESTAD, L. A., 1997, Toxicity of acid aluminum-rich water to seven freshwater fish species: A comparative laboratory study. Environ. Pollution, 96: 129-139.

POWER, M. E., 1984, Habitat quality and the distribution of armored catfish in a Panamanian stream. J. Anim. Ecol., 53: 357-374.

POWER, M. E., 1990, Resource enhancement by indirect effects of grazers: armored catfish, algae, and sediment. Ecology, 71(3): 897-904.

SCHAEFER, S. A \& LAUDER, G. V., 1986, Historical transformation of functional design: evolutionary morphology of feeding mechanisms in loricarioid catfishes. Systematic Zoology, 35(4): 489-508.

SCHOENER, T. W., 1974, Resource partitioning in ecological communities. Science, 185: 27-39.

VAL, A. L. \& ALMEIDA-VAL, V. M. F, 1995, Fishes of the Amazon and their Environment: Physiological and Biochemical Aspect. Springer-Verlag, New-York, 224p.

WETZEL, R. G., 1993, Limnology. W. B. Sauders Company, Toronto, $919 \mathrm{p}$.

ZAR, J. H., 1996, Bioestatistical analysis. Prentice Hall, New Jersey, 662p. 